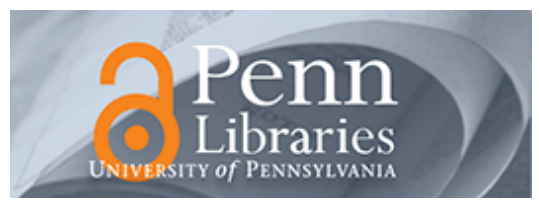

University of Pennsylvania

ScholarlyCommons

January 2008

\title{
"It Takes a Village to Raise a Child": The Role of Social Capital in Promoting Academic Success for African American Men at a Black College
}

\author{
MaryBeth Gasman \\ University of Pennsylvania, mgasman@gse.upenn.edu \\ Robert Palmer \\ Morgan State University
}

Follow this and additional works at: https://repository.upenn.edu/gse_pubs

\section{Recommended Citation}

Gasman, M., \& Palmer, R. (2008). "It Takes a Village to Raise a Child": The Role of Social Capital in Promoting Academic Success for African American Men at a Black College. Retrieved from https://repository.upenn.edu/gse_pubs/173

Copyright (C) 2008 The Johns Hopkins University Press. This article first appeared in Journal of College Student Development, Volume 49, Issue 1, January, 2008, pages 52-70.

Publisher URL: http://muse.jhu.edu/journals/journal_of_college_student_development/

This paper is posted at ScholarlyCommons. https://repository.upenn.edu/gse_pubs/173

For more information, please contact repository@pobox.upenn.edu. 


\title{
"It Takes a Village to Raise a Child": The Role of Social Capital in Promoting Academic Success for African American Men at a Black College
}

\author{
Abstract \\ Historically Black colleges and universities (HBCUs) were created to provide educational opportunities for \\ African Americans when other higher education venues restricted their participation. HBCUs are credited \\ with nurturing and producing leaders who embraced W. E. B. Du Bois's concept of the "Talented Tenth," \\ and exhibiting fortitude in advancing social equality for all. Over the years, as legalized segregation was \\ overturned and efforts were made to expand opportunities for African Americans, some have questioned \\ the continuing need for HBCUs. A study of 11 African American men attending a public, urban HBCU, \\ indicated that the university's rich supply of social capital (a direct consequence of its mission and \\ history) makes it a unique fixture in the landscape of higher education, one whose special features have \\ not been replicated by historically White institutions.

\section{Comments} \\ Copyright @ 2008 The Johns Hopkins University Press. This article first appeared in Journal of College \\ Student Development, Volume 49, Issue 1, January, 2008, pages 52-70. \\ Publisher URL: http://muse.jhu.edu/journals/journal_of_college_student_development/
}




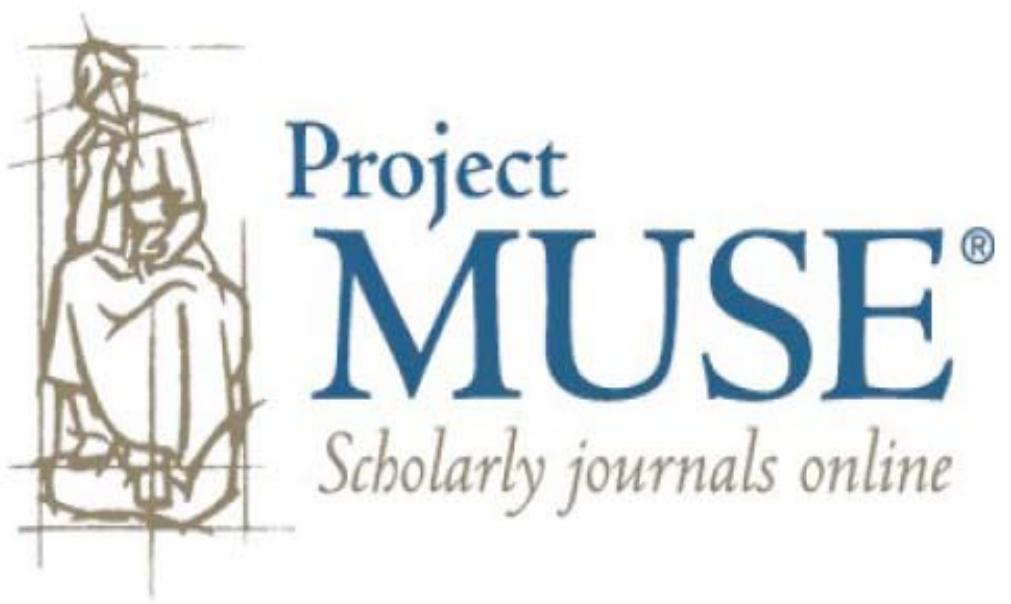




\title{
"It Takes a Village to Raise a Child": The Role of Social Capital in Promoting Academic Success for African American Men at a Black College
}

\author{
Robert Palmer Marybeth Gasman
}

Historically Black colleges and universities (HBCUs) were created to provide educational opportunities for African Americans when other higher education venues restricted their participation. $H B C U_{\text {s }}$ are credited with nurturing and producing leaders who embraced W. E. B. Du Bois's concept of the "Talented Tenth," and exhibiting fortitude in advancing social equality for all. Over the years, as legalized segregation was overturned and efforts were made to expand opportunities for African Americans, some have questioned the continuing need for HBCUs. A study of 11 African American men attending a public, urban $H B C U$, indicated that the university's rich supply of social capital (a direct consequence of its mission and history) makes it a unique fixture in the landscape of higher education, one whose special features have not been replicated by historically White institutions.

Historically Black colleges and universities (HBCUs) have served an important role in promoting access to higher education for African Americans when other venues were closed to them. During their inception, HBCUs were far from equal in terms of infrastructure, resources, and operating budgets; these inequities persist to the present day (Anderson, 1988; Brown \& Davis, 2001; Brown, Donahoo, \& Bertrand, 2001; Drewry $\&$ Doermann, 2004). Despite the lack of resources, HBCUs have a rich legacy of producing charismatic leaders (for example,
W. E. B. Du Bois, Martin Luther King, Jr., Thurgood Marshall, Ella Baker, Barbara Jordan, and Stokely Carmichael) who valiantly advocated for societal change for all and served as positive role models to many African Americans. Black colleges also provide a rich source of social networks to students, fostering an empowering educational climate. However, as legislative and programmatic initiatives have made it possible for African Americans to gain access to Historically White Institutions (HWIs), HBCUs have seen their enrollments drop drastically. At present, they enroll 16\% of African Americans at the undergraduate level (Provasnik, Shafer, \& Snyder, 2004). Furthermore, as governmental constituencies seek to eradicate de jure segregation by promoting student integration and eliminating program duplication (i.e., Adams v. Richardson, 1973; United States v. Fordice, 1992), some scholars fear that HBCUs may disappear (Blake, 1991; Brown \& Davis, 2001; Days, 1992; Stefkovich \& Leas, 1994).

The significance of HBCUs cannot be understated. At present, these institutions award nearly one-fifth of all bachelor degrees to African Americans. HBCUs also award 20\% of all first professional degrees (Hoffman, Liagas, \& Snyder, 2003). According to Allen (1992), these enrollment and degree statistics are significant, especially given that HBCUs represent only $3 \%$ of the nation's institutions of higher learning. Furthermore, despite

Robert Palmer is an academic advisor for the Comprehensive Program for Undeclared Majors at Morgan State University. Marybeth Gasman is Assistant Professor of Higher Education at the University of Pennsylvania. 
limited resources, HBCUs manage to create an environment in which African Americans are educated regardless of academic preparation, test scores, socioeconomic status, or environmental circumstances (Allen \& Jewell, 2002; Kim, 2002; Kim \& Conrad, 2006). Scholars argue that HBCUs are necessary because of their ability to educate many African American students who otherwise would not be able to study at the college level (Berger \& Milem, 2000; Brown \& Davis, 2001; Brown et al., 2001; Drewry \& Doermann, 2004; Freeman \& Cohen, 2001; Roebuck \& Murty, 1993). In this study, we draw from a qualitative study conducted with African American men attending a Black college to discuss the impact of social capital on academic success at this institution.

\section{REVIEW OF LITERATURE}

HBCUs were established with the assistance of the Freedman's Bureau, Black churches, Northern missionaries, private philanthropists, and governmental initiatives (i.e., Morrill Act of 1890) to provide access to higher education for African Americans. From approximately 1865 until the 1960s, the majority of African Americans who went to college attended these colleges and universities, which helped to promote their social equality and social mobility. These universities have nurtured strong, courageous leaders who helped to usher in social advancement for all Americans (Drewry \& Doermann, 2004).

Over the years, there has been a precipitous drop in the number of African Americans attending $\mathrm{HBCUs}$, prompted by several governmental initiatives (i.e., Brown v. Board of Education, 1954; Adams v. Richardson, 1973; The Civil Rights Act of 1964; and the implementation of the federal aid program). Whereas previously a critical mass of African Americans attended HBCUs, by 1973 three fourths of
African Americans were attending HWIs (Allen \& Jewell, 2002; Brown et al., 2001; Green, 2001; Moore, 2001).

Despite the decline in the number of African American students attending HBCUs, researchers have consistently argued that Black colleges and universities foster a nurturing, family-like environment, and faculty members are supportive of African American students (Brown et al., 2001; L. A. Davis, 2006; FriesBritt \& Turner 2002; Seifert, Drummond, \& Pascarella, 2006 ). African American students at these institutions are more satisfied, engaged in the community, and well-adjusted (Allen, 1992; Fleming, 1984; Fries-Britt \& Turner; Harper, Carini, Bridges, \& Hayek, 2004; Pascarella \& Terenzini, 2005).

Research has also shown that African American students on Black campuses exhibit positive psychosocial adjustments, cultural awareness, and increased confidence (Allen, 1992; Fleming, 1984; Fries-Britt \& Turner, 2002). African American students perform well academically, even though some students enter college with academic deficiencies and come from low socioeconomic backgrounds (Allen, 1992; De Sousa \& Kuh, 1996; Outcalt $\&$ Skewes-Cox, 2002). Up-to-date, comprehensive research on Black colleges' impact is sparse. However, past research has indicated that these institutions aid the growth and development of African American males. According to Fleming (1984):

Males in Black colleges exhibit the happiest adjustment to college life that can be found. Despite some ambivalence surrounding their interactions with teachers, their experience is more strongly characterized by absorption with role models, greater satisfaction, and positive outcomes from the educational experience, and gains in assertiveness of self-expressions and in dealing with others. (p. 168)

Fleming (1984) also explained that intellectual 
development is more positive for African Americans in Black colleges. These students experience more contact with faculty, experience greater satisfaction with their academic lives, and exhibit higher career aspirations. According to Fleming (1976), HBCUs are known for admitting students who are underequipped for college level work, improving their academic deficiencies, and graduating them with the skills to successfully compete in society. In fact, in a more recent article from Kim and Conrad (2006), who drew on data from the NCES, HBCUs continue to effect students in the way that Fleming described in 1976-having a value-added impact for students attending Black colleges. That is, students receive both a secondary and college education. Research also has indicated that the HBCU experience propels more African Americans into graduate and professional degree programs (Allen, 1991, 1992; Brown \& Davis, 2001; Brown et al., 2001; Garibaldi, 1997; Perna, 2001; Roebuck \& Murty, 1993; Wenglinsky, 1996). According to the United Negro College Fund (2007), of the top 10 colleges that graduate African Americans who go on to earn Ph.D.'s or M.D.'s, 9 are HBCUs, as are 8 out of the 10 top producers of African American graduates in mathematics and statistics. And the 12 top producers of African American graduates in the physical sciences are all Black colleges, including Xavier University of Louisiana, which is ranked first. In fact, Xavier is responsible for placing more African American students in medical school than any other institution in America. And, even more important, $92 \%$ of these students complete medical school and pass board exams. Moreover, Brown and Davis (2001) noted that "historically Black colleges remain the undergraduate home of $75 \%$ of all Black army officers, $80 \%$ of all Black federal judges, and $85 \%$ of all Black doctors" (p. 1).
Although some scholars have argued that HBCUs improve the social and academic experience of African American students, researchers have found that African American students attending HWIs often experience alienation and are not engaged in the campus (Allen \& Haniff, 1991; Feagin, Vera, \& Imani, 1996; Pascarella \& Terenzini, 2005; Rankin \& Reason, 2005; Tinto, 1987). Kimbrough and Harper (2006) asserted that "with much of the national attention being placed on issues facing African American students at predominantly White institutions ... the quality of life at HBCUs for African American students-especially African American menhas gone virtually unnoticed" (p. 190). Numerous researchers (Allen, 1987, 1992; J. E. Davis, 1994; Fleming, 1984; Fries-Britt, 1997, 1998; Fries-Britt \& Turner, 2002) have investigated the experiences of African Americans attending HWIs in comparison to HBCUs. However, many of these studies neglected to disaggregate the experiences of African Americans "by gender and achievement patterns" (Harper, 2007, p. 2). As such, a lack of current literature exists (e.g., Harper, 2006; Ross, 1998) to document the experiences of African Americans men at HBCUs, particularly those students who enter higher education as academically unprepared and persist to graduation. Consequently, this study seeks to help alleviate the dearth of knowledge about African American male experiences at HBCUs. In this paper, we discuss the results of a study of 11 academically underprepared African American men who entered a public, urban HBCU, in a mid-Atlantic state and were able to graduate in spite of their disadvantaged status. One of the salient factors that emerged from this study is the abundance of social capital at this HBCU and its impact on fostering academic success. The goal of this paper is to illuminate the many examples of 
social capital that positively influence retention and persistence for African American men.

\section{CONCEPTUAL FRAMEWORK}

According to Bourdieu (1986), social capital refers to the ways in which some individuals are privileged because of their membership in a social network. He posited that the amount of social capital individuals possess hinges on the size of their network as well as their economic and cultural standing. Importantly, Bourdieu viewed social capital as a mechanism of control that the ruling classes use to maintain their dominant position over the general population (Lin, 2001). In this way, social capital can be seen as a negative attribute; however, when members of the underclass gain social capital, they can act in ways that disrupt the influence and power of the upper class. In Coleman's (1988) words, social capital consists of a variety of entities, embedded in social structures, which make possible the achievement of certain goals not plausible in the absence of such social structures. Coleman's conceptualization of social capital is premised on understanding the norms, trust, authority, and social control that an individual must learn to succeed. Anheier, Gerhards, and Romo (1995) provided a more lucid explanation of social capital. They explained that social capital "is the sum of the actual and potential resources that can be mobilized through membership in a social network of actors and organization" (p. 862). According to Brown and Davis (2001), social capital "is a type of resource that is socially reproduced, such as the possession of knowledge, accomplishments, or formal and informal relations and network" (p. 41). By means of social capital, individuals may gain support from a social network, which facilitates the awarding of "social rewards, such as status, privilege, and positions in certain social circles, professions, or organization" (Brown \& Davis, p. 41). Brown and Davis also asserted, "The relations and networks that Black colleges construct into tangible and meaningful resources are known as social capital" (p. 41). In other words, the phenomenon that Bourdieu (1973, 1976) and others have discussed in theory is actualized in the Black college setting.

Though researchers (Farmer-Hinton \& Adams, 2006; Perna \& Titus, 2005; Smith, 2007; Tierney \& Venegas, 2006) have used social capital to examine access, retention, and persistence for college students in the contexts of supportive relationships within the college community (e.g. mentors, peers, and counselors), there are few studies (e.g., Brown \& Davis) that have examined social capital and its impact on fostering student success at Black colleges. In this study, we applied Brown and Davis's (2001) delineation of social capital, which espouses the social networking and supportive relationships that exists at Black colleges, to draw on examples of the social capital that permeates the Black college campus and their impact on supporting academic achievement for African American men.

\section{METHODOLOGY AND DATA COLLECTION}

We conducted this study at a public, doctoral research intensive $\mathrm{HBCU}$ in a mid-Atlantic state. According to the Office of Institutional Research (OIR) at this university, approximately 6,000 undergraduate and 400 graduate students were enrolled when data were collected. With regard to the freshmen class, the average high school grade point average (GPA) was 3.00. Twenty-four percent of the new students scored over 500 on the SAT verbal exam, and $25 \%$ scored over 500 on the SAT math exam.

We used a qualitative approach to guide 
this study because we sought to understand the social experiences of African American men in a particular context. Specifically, we used the case study approach as we collected data from multiple sources of information through an extensive exploration in a bounded system. As such, our epistemological approach was anchored in the constructivist tradition to build knowledge, understanding, and meaning through human interactions (Jones, Tores, \& Armino, 2006).

Participants for this study consisted of African American male juniors and seniors who entered a public HBCU through its precollege program and persisted to graduation. The pre-college program serves as an intervention for academically unprepared students who do not meet traditional academic standards (i.e., GPA, SAT scores, and ACT scores) for admission to the university. Students in this study participated in this 6-week intensive summer preparatory program to strengthen their academic skills for college. To complete the program successfully, students must earn at least a grade of "C" in all pre-college courses, complete all assignments, and attend all scheduled events.

\section{Procedures and Participants}

The university's OIR provided us with a list of 111 African American male students who entered the university through its pre-college program during the summers of 2000 through 2003. Of the 111 students, we contacted only 73 students given that 38 had graduated. We e-mailed the 73 potential students a poster about the study and asked them to contact us if they were interested in participating. We later followed the e-mail with a letter to their on-campus and home residences. As an incentive, we offered participants a $\$ 20$ gift certificate. We also sought the help of staff members (or gatekeepers) at the university whom we believed knew students who matric- ulated to the university through the pre-college program (Creswell, 2003). The staff members identified and contacted students who met the criteria for the study, which also enabled us to gain the confidence of our participants (Creswell, 2003)). We recruited additional participants through snowball sampling (i.e., asking those who joined the study to recommend others who might meet our criteria).

Although 73 students were contacted, few displayed an interest in participating in the study. With snowball sampling and help from university administrators, we recruited 11 African American men to participate. The average student involved was 21 years of age, majored in business, had earned 93 credits, and had earned a 2.7 GPA. Participants' fathers' occupations included a teacher, lawyer, police officer, minister, and maintenance worker, and their educational attainment ranged from a GED to professional and graduate school. Participants' mothers' occupations included a pediatrician, minister, congressional representative, daycare worker, and United States Postal Service worker. Participants' mothers' educational attainment ranged from high school to medical school. Seven participants were raised in the suburbs, 3 were raised in a large city, and 1 was raised in a small city. Many of the participants came from a two-parent household. Most of the participants planned to further their education beyond their baccalaureate degrees. Specifically, 4 participants planned to obtain doctoral degrees, 6 planned to obtain master's degree, and 1 participant did not have plans to further his education.

We conducted 70-90 minute, face-to-face, in-depth interviews with each participant. All interviews were completed within 6 weeks. Prior to beginning the interviews, participants signed a consent form, completed a brief demographic form and a short open-ended questionnaire to help us understand factors 
germane to their academic success. With the participants' consent, we also obtained information about their grades and GPA from the director of the pre-college program, who had tracked the participants' academic progress since their matriculation into the university. During these interviews, we engaged participants about their academic and social experiences at the university. We placed particular emphasis on understanding their pre-college experiences and investigating key factors to their success. Many of the questions were open ended, which enabled participants to talk in depth about their experiences. We recorded our observations regarding how the participants responded to a question and their willingness to engage in the interview. We also conducted follow-up phone interviews with participants to clarify issues that emerged. We audio taped and transcribed all of the interviews.

\section{Data Analyses and Reporting}

We used constant comparative analysis on field notes, observations, and interview transcripts. According to Jones et al. (2006), constant comparative analysis engages the researcher in a process of collecting and analyzing the data simultaneously at "all stages of the data collection and interpretation process, and results in the identification of codes" (p. 44). We used ATLASTI, a qualitative data management software program, to organize, manage, and code the data. We used open coding to identify themes, analyzed the interview data obtained from each participant independently, and included cross-case analysis as well (Yin, 2006). In discussing the findings, we present excerpts from the participants' responses verbatim to paint a picture of the participants' voices. We used pseudonyms to maintain the anonymity and confidentiality of each participant. In addition, we excluded information that would compromise the confidentiality of the participants, administrators, faculty, and staff.

\section{Credibility}

We employed several techniques presented by Merriam (1998) to ensure credibility of the study. For example, we provided thick description in the article so that others interested can draw their own conclusions from the data. Moreover, providing thick description enables the reader to vicariously experience the participants' challenges at the university and the strategies they employed to surmount them.

We also returned the transcribed interviews to all participants so they could check for accuracy and clarity in the information from open-ended interviews. Lastly, we used feedback from five peer debriefers who were well versed in the topic of exploration and case study methods. These debriefers provided their own interpretations of the themes from the data to ensure creditability (Jones et al., 2006).

\section{LIMITATIONS}

A limitation of qualitative research is that the findings can only be generalized to other cases similar to the case of focus. Moreover, interviews may not be an effective way to collect reliable information when the questions pertain to matters the participants perceive as personally sensitive.

We proceeded with the qualitative methodology because we were interested in investigating the social experiences of academically unprepared African American men. We specifically focused on African American men at a Black institution because of the scarcity of research on retention and persistence for African American men attending Black colleges and universities. 


\section{FINDINGS}

The data from this study contribute to the literature by examining manifestations of social capital and their impact on success for academically unprepared African American men attending an HBCU. The participants indicated that professors and administrators were accessible and displayed a willingness to form supportive relationships with students. These relationships encouraged persistence because the students realized that professors and administrators cared about them and their success at the university. Faculty and administrators mentored and served as role models for many of the students. They also directed and encouraged student participation in student support services, campus organizations, internships, and scholarship programs. Participants reported relying on peers to sustain their motivation, to provide a cathartic outlet, and for academic or social networking. They also indicated that the institution's community functioned as a purveyor of social capital and reported feeling valued, challenged, supported, and nourished.

We have grouped our findings according to five themes. First, we discuss participants' relationships with faculty. Next, we explain participants' reflections of campus administrators. Then, we describe participants' relationships with people they regarded as mentors and role models. In addition, we discuss participants' interactions with their peers and how they helped strengthen students' resolve to succeed. Finally, we include participants' reflections on the overall climate on campus.

\section{Faculty Relationships: Displaying Empathy and Support}

Participants commented on the linkage of helpful and encouraging faculty to academic success. Faculty supported these students by displaying concern, not only for their academic success, but also for their personal welfare. Faculty members displayed empathy for their students and tried to help students maximize their potential. James, a business major, noted the importance of building rapport with faculty by taking initiative to interact with them during their office hours. He emphasized that these relationships enabled his professors to know that he is diligent about his studies and serious about succeeding academically:

All of my teachers know me on a first name basis. I'm able to make that relationship with them, and they know if I'm trying or if I'm not, or you know, they just know me personally, so I've been able to make that relationship with them, so it kind of helps me out.

James also explained that some of his African American professors try to maximize his potential because they realize that he is capable of excelling academically.

Most of them are Black, which I do appreciate because what I learned now is that the teachers who are not Black usually ... water things down. So I feel like the Black professors are usually harder, because they know that you have the potential and they'll push you, and drive you, which of course will only help you in the long run.

Anderson, a theater major, commented on the faculty's caring and concern for his welfare and how this extended beyond academic issues. He also explained that faculty members were there for him and took extra time to make certain he understood the information presented in class:

Yeah, faculty has been great man. I always tell myself, "[If I had] gone to another university, would I have gotten this experience?" I hear people say bad things about the [university] to me; it doesn't get 
any better than this. The faculty really has just cared beyond caring, you know. These are people with doctoral degrees, "Like why are you even talking to me? Like what can I offer you?" Absolutely nothing! I have no money. I have no advice to give you. I have nothing to offer you. Yet you sit down for hours and you just try to help me. I come to your office and you sit there for an extra hour, and it's just amazing. I never knew people [could] be that generous. I didn't know that kind of generosity still existed. I thought it died out in the 60 s.

Samuel, a sociology major, also commented on how his professors made themselves available and accessible:

Knowing the professors there, [one professor] has really stepped in. . . . You can email [him]. You can call him. You can knock on his door. He's open and willing to tell you things that some professors won't tell you. He's willing to tell you things that you just need to know, but somehow do not know. He takes the extra initiative.

Many of the participants conveyed that faculty took a genuine interest in getting to know them and building relationships with them. They developed an interest in the students' academic and personal lives and made attempts to relate to the students' life situations. This approach strengthened the faculty members' overall rapport with the students.

Robert, a business major, commented on how he felt faculty created a warm, welcoming environment, indicative of a "home away from home," which is additional evidence of the care and concern faculty display for their students.

Especially for the people that . . . don't live here ... you might not always have the opportunity to run home, run to a family member. Plenty of professors and advisors [here] care [about you]. You may not get home, but here they try to make it home.

Wilson, a physical therapy major, underscored how faculty demonstrated empathy based on their own experiences and established a supportive relationship with students:

We had an assignment-we had to write an essay talking about something that happened in the past. I wrote a essay about, I don't even remember what the essay was about, but the professor came to me after class and was like, "Oh, you know I went through the same thing or you know if you have any problems, you can call me." She gave me her phone number, her email address. I was able to call her if I had problems with homework, or if I needed help with the assignment.

Faculty went beyond their professional duty to form supportive relationships with students. They created a close-knit community in which out-of-state students felt a part of the institutional fabric of the campus. They also used empathy to foster a better connection with the students, helping students to personally identify with faculty. Furthermore, students reported that African American professors tried to maximize their potential because they knew that the students possessed the capability, desire, and motivation to achieve.

Going Above and Beyond the Call of Duty: Supportive Administrators and Academic Success

Participants commented that administrators are another vital component of the support system. These administrators are helpful, accessible, and demonstrate a caring attitude about student success. Anderson felt:

There's ... staff and sometimes I forget they work here because they're so kind, and so generous. ... Y You become on a first name basis with people because they 
just take you under their wing as a freshman and they show you that [there's] more to school than doing well. If you have a bad semester, if you have a bad class, [they say], "Come talk to us. We'll work these things out for you and we'll try to help you." The whole honors department . . . really care about their students and care about their work, and you begin to really care so much about these people ... if you do not do well, it will not only hurt you, but it will hurt them. You become more concerned about not hurting them that you try so hard. Those things helped me, having administrators that actually care. . . . Like Dr. Howard, her door is always open. I asked the lady one day "When do you get any work done because you always help students in here?" She just replied simply, "The students are my life," and I was like, "Damn.”

Lawrence, a sociology major, concurred with Anderson's assertion of the importance of supportive administrators. "You know the administrators and staff - they all got open arms, so they're willing to mentor you without you even knowing you're being mentored." Continuing, Lawrence indicated,

Mr. Jackson helped me out. He mentored me, you know, coaches, you know, different teachers, you know. I mean even though [they're] teaching so many different students, they care about the students and want you to succeed, so they'll go the extra mile and help you out if you really need it.

Samuel echoed this sentiment: "You can look up to them, people that really care, not telling you what you want to hear, more so telling you things that can really impact your life, making it comfortable here." Students commented that some administrators, much like faculty, took a personal interest in the students and were supportive. These administrators adopted an "open door policy" and illustrated care that extended beyond their academic performance. Some of these administrators also served as role models and mentors to these students, which illustrated the richness of social capital at this institution.

\section{"My Brothers' Keeper": Relying on Peers for Motivation and Encouragement}

In addition to faculty and administration, numerous participants explained that their peer groups significantly influence their academic achievement. James indicated he strives to create a community of peers who are motivated, persistent, and work diligently toward their educational aspirations. He strongly believes that his peers fuel his desire and drive to become academically successful:

Most of my friends . . . they have goals, they're ambitious, they have drive, passion. I try to keep people like that close to me and I think that's how that's changing me, because I kind of emulated them in a way; it kind of made me become more focused.

He elaborated,

If I didn't surround myself with people who are hardworking, intelligent and ambitious, I think it would be difficult because I do believe that you feed off your friends. I mean you choose your friends ... who you choose is very important. If I didn't have the friends that I have now it would be hard to be successful because we all want to go to the same place; we all see ourselves as successful.

Anderson commented on the positive impact peers had on his academic achievement. Specifically, he explained that peer pressure enhanced his motivation and desire to perform well:

If you got a whole bunch of friends pressuring you to do well, you don't really have a choice if you want to stay with that group to do well, and peer pressure might 
sound very elementary but it's true. I don't care how old you get, it's very true. I was indirectly pressured into doing well through others.

Chris, an industrial engineering major, agreed that one's social network has personal implications for success. "People that you hang around, they could lead you into doing things you don't want to do so, you also have to hang around people who have the same goals and drive as you." Many participants commented on how their peers encouraged and motivated them to succeed academically. For example, Simmons, a business major, explained that sometimes you have to act as a figure of authority to peers to ensure that they do not lose their focus. Specifically, he said,

One of my good friends he had a 0.7 [GPA] . . . As friends . . . if somebody is down, we have to bring them up by talking to them, encouraging them ... making sure that they are doing their work. Even though they might be of age, you still have to [be a father figure and say], "Did you do your work? . . . Did you do homework? Do you have homework?"

Robert also explained how one of his peers encouraged him to persist: "I found two of my friends through the precollege program.... Whenever we need to be encouraged, we just encourage each other, 'Like don't give up, don't give up.' I mean, it's the good support system that Black men need." He added:

Some of the buddies . . .who I've formed friendships with are ... the ones who have really like challenged me to like, to not be discouraged because in college there are a lot of times your buddies are graduating early before you, or they're way past graduation . . . but you're still here, still stuck in that one class.

Douglass, a business major, also agreed with how his peer group encouraged and motivated him. He noted:
Having friends that have the same common goals as I do, that inspires me to push myself even farther, 'cause they all have personal achievements, and it's not a competition thing. It's all about uplifting one another, and pretty much have all your goals set, one day at a time when you look to the future 5 years from now, paying loans off, debts, buying houses, investments, and if you are planning for retirement, you'd be thinking long-term, that's the way our mind-set is.

Lastly, Chris expressed how his peers provided a support system for him. They keep him invigorated, and provide an outlet to relieve stress, as well as help him focus on his goals. He noted:

[Friends] give you another reason to stay in school 'cause a lot of people, they commit suicide and 'cause of stress, 'cause nobody loves them. I didn't realize how important friends are. . . Even though I got brothers and sisters ... friends are really important, 'cause you're going to need the support and all.

By forming supportive relationships with other students, which facilitates perseverance and persistence toward the goal of graduation, peers provide a rich source of social capital. Although not explicit, it is plausible that without the relationships students have with their peers, their academic success would be hindered. The participants reported that their friends encouraged their persistence by displaying concern for their academic success, motivating them to persist, and acting as authority figures.

\section{Role Models and Mentors: Using Wisdom, Dedication, and Experience to Illuminate the Pathway Toward Success}

Many participants explained how, in addition to peer relationships, access to role models and mentors emerged as a significant factor to 
support academic success. James noted that having access to someone who has been successful certainly affects success.

I think ... if maybe we can reach out to the freshmen more. If they know that, you know, I was in the same position as [them]. I was in pre-college, and now ... I'm graduating . . . and you know I'm in these organizations.

Anderson agreed with James's assertions, but added that having some commonalities (e.g., gender, ethnicity, educational background, socio-economic status) with the successful person can foster a sense of self-efficacy. Recalling a visit by Dancy, an alumnus and successful lawyer, Anderson explained,

I think it's . . . a male seeing another male doing something that he wants to do. Dancy is [on] the university council, and he came down to my [residence hall] one time. I invited him to come down and speak with some of the guys when I was a RA. A lot of people said I want to be a lawyer. I want to be a doctor, but you don't see any Black lawyers, you don't see any Black doctors, how feasible [is it] to ever reach that goal if you don't see anyone that looks like you? So when he came down, that guy is young, man. He's a lawyer really, in actuality that's instant inspiration because you're like, "If he could do it, I could do it, he looks just like me." So I think males on campus, African American males in general, on a college level, if you see someone doing something that you want to do, it will inspire you to do it.

Anderson added,

But when you see someone that's not like you, and you want to do it . . . it's already enough stacked up against the Black male, and I'm not saying there's some external force that's trying to keep the Black male down. Personally, I think a lot of what keeps us down, is ourselves. But the inspiration you can get when you see another [Black] man doing what you want to do, there's nothing like it. That's why I think a lot of students or a lot of [Black] males want to be athletes, because that's all they can see, or they want to be musicians, 'cause that's all they see. But if you saw a whole bunch of Black doctors running around all day, and saving lives, that's what you want to do, because it's feasible.

Walter, an architecture major, talked about how his fraternity brother on campus serves as a positive influence on his success. Specifically, he stated,

Well, my brother in the fraternity and I have a wonderful relationship. He continues to look out for me. He's always supportive of me, man, and he is a role model for me as well. ... I look up to him a lot. He was academically successful and he's here to serve as a motivational tool. Again, it's just a continual process of motivation.

Douglas also indicated that access to role models drives success. "I say have more Black male role models. Because if you have Black male role models, you'll look at them and say, 'This person has been in the same situation I have, and look how successful he is."”

Participants identified a relationship between mentoring and persistence. Access to mentors is important because they provide support and guidance. Simmons offered this explanation about mentoring:

Mentoring has played a big part because if mentoring wasn't there, I think I'd probably failed my English class-my freshman year. The teacher ... how she used to want us to write our papers, was very different from what I was used to. So the first paper I wrote, she failed me. She gave me a 50 or something on it. ... So I let my mentor read it, and ... [he] thought it was okay, but when I explained to ... [him] how ... she wanted me to 
write it, then he understood it more and then he helped me out a little more with it. So after that, I passed the class with a $B$.

Robert agreed that mentoring had a significant impact on academic success. He encouraged young students to form a mentorship with someone older. This mentorship would positively enhance students' success because they would have access to an experienced person to help them navigate the rough terrain of college life and circumvent the pitfalls that lead to poor academic performance. In Robert's words,

I think that . . older Black men need to sit down with younger Black men and just rap together, just talk. I mean not about just hip-hop, but about growing up, dealing with women, dealing with living on your own, because when you grow and you move out on your own, it's hard, especially if you're from a different state. It's kind of like, moving to a different country, 'cause you don't know anybody. So you're dealing with all this temptation and it's like. I remember there is a Bible verse that says, "The old know the way, the young they have strength." The old are wise because they know the way, but the young, they're good because they're strong. I mean it's all about connecting with Black men who know the way already.

And, Walter emphasized the centrality of a mentor to academic success:

I know one of the most important things, I've probably said this about a billion times already, is to get a mentor. You must get a mentor. Without a mentor, you're lost. Without anybody to look up to, it's like you don't have a sense of where you could be. One of the first things I got was a mentor around this campus; my grandfather introduced me to Dr. Lattisaw. And once you start talking with mentors and socializing, you begin to understand . . . and start setting goals for yourself, and ... then you can go from there, and whenever you need him, he'll be there. It's like a brotherly relationship, and also like a parental figure.

Like peers, mentors and role models provide a lavish source of social capital, particularly in the contexts of HBCUs. They provide guidance, nurturing, social networks, and encouragement, and help socially integrate students into the university's community.

\section{Supportive Campus Community and Success}

Many participants described their university's environments as supportive and caring. Anderson noted that it is hard to identify one factor at this HBCU that has enabled him to succeed. He credited all of the university personnel (i.e., faculty, administration, and staff) for providing a source of support, motivation, and words of encouragement. Specifically, he said,

It's just the environment that the [university] fosters. When I came here, it's so hard to pinpoint one thing that really got me to this point. 'Cause one without the other, it's like mayonnaise without bread, I mean like you know, you've got to have a sandwich in order to get what you want. Everything here at the [university] just came together to get me to this point. ... The most important thing, I think it was the administration and the faculty and the staff that helped me out. From talking to maintenance staff who tells you to stay in school, from talking to a doctoral student, or someone with a Ph.D. telling you to file your taxes, it all broadens to this point. So, it's hard to pinpoint one thing.

Lawrence agreed that the university offered a family-like environment. "There's really good people on campus that really care about you and it's all been an uphill ride for me since I've 
been at the [university]."

Although Walter described the [university] as supportive, he noted that students need to be proactive about seeking assistance:

It's important for the student to take action. Don't expect teachers to go running after you. ... If you don't seek help, they will probably assume that you don't need it. [Faculty will] always be available to you, [but] you have to take the opportunity [to seek support]. Be prepared for the opportunity when it presents itself.

James mentioned that social support systems at the university helped him to raise his GPA: "The social aspect is completely different at Black colleges, which I'm very thankful for. I probably wouldn't have the grades I have [elsewhere].” James also offered that a HWI seemed to be less personal [based on his visits with friends at HWIs], whereas an $\mathrm{HBCU}$ seems more personal. He indicated that professors are available and demonstrate a willingness to build relationships with students:

At a predominantly White university, it's easy for you to just feel like a dot or just [a] number. But here, it's more . . . personal, it's more relationship-building ... it's very easy for you to go to your teacher and be like, "Listen I'm not understanding," and half the time they will take time out to help you. So, I think that's what it is-it's the smallness of the classes and the close feeling-you can really get to kind of know your teachers. So you don't get lost in the whole college setting. So I try to think of it ... it's the classroom sizes, which are good 'cause initially my whole vision of college was you know, I want to be in a classroom with 400 people. I wanted that, but now that I'm here, I'm really glad that I didn't because I'm so thankful that I'm in these small classes, and my teachers know me on a first and last name basis. That I can easily call them up and [say], "Hey I need a recom- mendation or I need help with this and that," [and] they have the time to devote to me.

Anderson, Robert, and Lawrence described the positive effect of the [university's] racial homogeneity. Specifically, they explained that having access to a cadre of African American students who are motivated and focused on attaining their baccalaureate degrees affects their motivation to succeed. Simmons articulated, "It's like most of the African American males here are like we're striving for one thing - to be successful, and that makes me want to be successful." Robert commented:

Seeing other Black people [makes] us want to succeed too. Like so much of society, they show us as scavengers . . they show us as not intelligent. Corporate America shows us what they want us to see, and they show people what they want us to be thought [of as], and I don't like that. But when I came to the [university] . . . I saw Black people. I saw Trinidadian people. I saw people from all shades of Black . . . who [are] motivated [and] driven for success.

Lawrence added,

It makes you want to do better, 'cause you're at an institution with a majority of your race, and you don't want to be a failure. You want to succeed and you already know that some people will look at a HBCU as being on a smaller level, so you want to try to get the most out of it that you can.

Samuel stated that the environment at the [university] positively shaped his professional preparedness for the world. He reflected:

[The university] has groomed me and made me a contender for the world. Many times like I said when you [graduate from an] HBCU, people look at you ... . a little strange, but it's not where you come from, it's what you learned from where you 
come from. ... When someone sees my application, see my resume or something like that, they'll see the knowledge that I possess, that I can write and speak. I am marketable ... [the university] has made me a marketable, Black, young man.

\section{DISCUSSION}

The findings from this study are consistent with those of researchers who have characterized HBCUs as supportive and nurturing (Allen, 1987, 1991, 1992; Berger \& Milem, 2000; Fleming, 1984; Fries-Britt \& Turner, 2002). Brown and Davis (2001) noted that HBCUs are rich in social capital, which is positively related to academic success. At the HBCU in this study, the depth of social capital includes the entire campus community, which reinforces the adage that "it takes a village to raise a child." The participants indicated that professors and administrators were accessible and displayed a willingness to form supportive relationships with students. These relationships encouraged persistence because the students realized that professors and administrators cared about them and their success at the university. Faculty and administrators mentored and served as role models to many of the students. They also directed and encouraged student participation in student support services, campus organizations, internships, and scholarship programs. In many ways, the interactions and experiences created a climate that the participants considered to be supportive and nurturing. These relationships provided a rich source of social capital for the African American males at this HBCU that many minority students at HWIs may not experience.

Research has shown that positive studentfaculty interaction is linked to academic achievement and success for all students (Astin, 1993, 1999; J. E. Davis, 1999; Eimers \& Pike, 1997; Pascarella \& Terenzini, 2005). Although research supports this relationship between faculty interaction and success, scholars have indicated that generally African Americans lack close contact with faculty at HWIs (Allen \& Haniff, 1991; Feagin et al., 1996; Pascarella \& Terenzini, 2005; Rankin \& Reason, 2005; Tatum, 1997; Tinto, 1987; Watson et al., 2002). Conversely, some researchers have argued that students have close, supportive relationships with faculty at HBCUs (Allen, 1987, 1991, 1992; Berger \& Milem, 2000; Fleming, 1984; Fries-Britt \& Turner, 2002). In fact, L. A. Davis (2006) indicated that "at HBCUs, it takes the entire institutional family to produce competent graduates. The administration, faculty, staff, alumni, and community people who take a personal interest in the ... student act as an extended family" (p. 44). Guiffrida (2005) noted that faculty, like those at the university in this study, who do not limit their professional responsibilities solely to teaching and research but also work to enhance students' psychosocial and emotional development, are student-centered.

The perceptions of the African American males in this study mirror Allen's (1992) assessment of HBCUs. He asserted that "Black universities provide positive social and psychological environments for African American students that compare to those experienced by White students who attend [a] White University" (p. 40) and explained that the social aspects encompass networks of peers, social outlets, and supportive relationships. The psychological component, on the other hand, includes a heightened level of self-confidence and self-esteem and a sense of belonging and ownership of the campus. Green (2000) explained, "The collegiate experience for African Americans at HBCUs is a cathartic one, in that it is a nurturing environment; faculty members at HBCUs discern student's difficulties and offer to them the social, cultural, and psychological support" to achieve and thrive academically (p. 16). 
The link between peer interaction and academic success noted in our findings is consistent with earlier research (Astin, 1999; Guiffrida, 2005; Harper, 2006; Kuh, Douglas, Lund, \& Ramin-Gyurnek, 1994 ; Pascarella \& Terenzini, 2005; Thomas 2000). Davis, Jenkins, Hunt, and Page (2002), authors of The Pact, attributed their cohesive relationships with each other as helping to successfully navigate medical and dental school. Furthermore Astin (1993) stated, "Student interaction with peers can positively influence overall academic development, knowledge acquisition, analytical and problem-solving skills, and selfesteem" (p. 45). Astin (1999) also found that the greatest source of influence on cognitive and affective domains is the student's peer group. Additionally, research from Thomas suggested, "Those students with a proportion of ties to their peer group perform better academically and are more likely to persist" (p. 609). He explained that a portfolio of relationships improves persistence by providing access to academic and social resources. At the HBCU in this study, peers provided a social network for students to access for support, encouragement, and motivation. The participants' peers provided them with a rich source of social capital, which positively enhanced their academic performance and success.

Additionally, in this study we found that accessibility to mentors and role models is related to academic success. This finding is consistent with current literature (Craig, 2006; Green, 2000; Ross, 1998; Tinto, 1987; Wallace, Abel, \& Ropers-Huilman, 2000). For example, Lavant, Anderson, and Tiggs (1997) found that when universities have implemented mentoring programs, African American men have been more successful academically. They highlighted six mentoring models at various institutions: (a) The Black Man's Think Tank, (b) The Student African American Brother- hood, (c) The Black Male Initiative, (d) The Meyerhoff Program, (e) The Bridge, and (f) The Faculty Mentor Program, all of which have been instrumental in reducing attrition for African American males. Although there are some differences among these programs, they provide a safe place for African American men, help them to cultivate leadership skills, and develop positive mentoring relationships with the university's constituencies. Institutions such as City University of New York and the University of West Georgia have implemented programs designed to enhance African American male retention (Holsendolph, 2005; Watson, 2006 ). This list is not exhaustive, as there are similar programs at many of institutions across the country. Participants indicated that mentors and role models provided guidance, nurturing, social networks, support, and encouragement.

\section{CONCLUSION}

HBCUs serve as important promoters of African American social mobility. Though fraught with economic inequalities in comparison to their HWI counterparts, they can be credited with nurturing the academic talents and potential of their students, many of whom have made great contributions to society. These 11 participants attending an HBCU have described an environment that was supportive, encouraging, and nurturing, enabling them to overcome their academic weaknesses and to graduate with a relatively strong GPA. The findings from this research support Brown and Davis's (2001) supposition that HBCUs are purveyors of social capital. The participants emphasized that these relationships were not limited to student affairs practitioners. Rather, the relationships encompassed the entire university community, including professors, administrators, staff, and peers. Faculty went beyond their formal roles 
to build a sense of connection with students; they listened, supported, demonstrated empathy, and displayed a concern for students' academic and personal well-being. Some administrators also possessed these qualities of warmth and concern, and established a rapport with students. Peer influence emerged as a vital aspect of social capital. Students encouraged their fellow students to persist by staying focused on their goals and completing assignments in a timely manner. Some participants commented that the university created a family-like environment that nourished students' talent and developed their potential.

As the results from this study were predicated on research from one Black college, additional research is needed across various types of HBCUs to see whether these findings are applicable to other HBCUs. A study of this magnitude is important because it would not only put into practice Brown and Davis's (2001) supposition that HBCUs must continue to be studied for their contribution to higher education, but also it might provide further evidence that these institutions are still significant in the landscape of higher education.

\section{RECOMMENDATIONS AND IMPLICATIONS FOR INSTITUTIONAL POLICY AND PRACTICE}

Several implications for policy and practice can be derived from this study. From a practitioner perspective, universities, regardless of institutional type, should note the importance of the university community working collectively to support students' academic success at Black colleges. This article demonstrates that success in college does not lie in the hand of any one person; rather, the entire university community is responsible for deploying social capital in a way that promotes student persistence and retention. College and university administrators should consider urging faculty to move beyond their prescribed roles of teaching and research to establish meaningful relationships with their students. Faculty should consider collaborating with student affairs practitioners to explore creative ways that they can work in tandem to enhance student success. To encourage faculty to become more supportive of students, universities should place more emphasis on student advising and mentoring in the criteria for tenure. Specifically, universities and colleges should contemplate implementing programs to encourage faculty to serve as mentors to students, particularly students who are at risk, as they may need more support and guidance.

Furthermore, college and universities should encourage administrators and other personnel of the institution to go beyond their prescribed roles to support students' success. These individuals can support, encourage, guide, mentor, and serve as role models to students. This synergy will ensure that the campus is truly a supportive enclave and place a strong emphasis on creating an environment that values student persistence and success.

Student affairs practitioners should consider encouraging students to form supportive, nourishing relationships with their peers. As such, students will have a strong social network to access should they encounter a problem, or need assistance or a listening ear. Additionally, student affairs practitioners, especially those who operate within academic departments, should also advocate for faculty's employment of collaborative learning approaches, which would give students an opportunity to increase their peer network and support circles.

Correspondence concerning this article should be addressed to Robert Palmer, 1531 Pentridge Road, Apartment402A, Baltimore,MD 21239; Ship2westster@ gmail.com 


\section{REFERENCES}

Adams v. Richardson, 351 f.2d 636 (D.C. Cir. 1972).

Anderson, J. (1988). The education of Blacks in the South, 18601935. Chapel Hill: University of North Carolina Press.

Allen, W. R. (1987). Black colleges vs. White colleges: The fork in the road for Black students. Change, 19(3), 28-34.

Allen, W. R. (1991). Introduction. In W. R, Allen, E. G. Epps, $\&$ N. Z. Haniff (Eds.), College in Black and White: African American students in predominantly White and in historically Black public universities (pp. 1-14). Albany: State University of New York Press.

Allen, W. R. (1992). The color of success: African American college students outcomes at predominantly White and historically Black public colleges and universities. Harvard Educational Review, 62(1), 26-44.

Allen, W. R., \& Haniff, N. Z. (1991). Race, gender, and academic performance in U.S. higher education. In W. R., Allen, E. G. Epps, \& N. Z. Haniff (Eds.), College in Black and White: African American students in predominantly White and in historically Black public universities (pp. 95-109). Albany: State University of New York Press.

Allen, W. R., \& Jewell, J. O. (2002). A backward glance forward: Past, present, and future perspectives on historically Black colleges and universities. The Review of Higher Education, 25(3), 241-261.

Anheier, H. K., Gerhards, J., \& Romo, F. P. (1995). Forms of capital and social structure in cultural fields: Examining Bourdieu's social topography. The American Journal of Sociology, 100(4), 859-903.

Astin, A. W. (1993). What matters in college: Four critical years revisited. San Francisco: Jossey-Bass.

Astin, A. W. (1999). Involvement in learning revisited: Lessons we have learned. Journal of College Student Personnel, 40(5), 587-598.

Berger, J. B., \& Milem, J. F. (2000). Exploring the impact of historically Black colleges in promoting the development of undergraduates' self-concept. Journal of College Student Development, 41(4), 381-394.

Blake, E., Jr. (1991). Is higher education desegregation a remedy for segregation but not educational inequality? A Study of the Ayers v. Mabus desegregation case. Journal of Negro Education, 60, 538-565.

Bourdieu, P. (1973). Cultural reproduction and social reproduction. In R. Brown (Ed.), Knowledge, education, and cultural change (pp. 71-112). London: Tavistock.

Bourdieu, P. (1977). Cultural reproduction and social reproduction. In J. Karabel \& A. H. Halsey (Eds.), Power and ideology in education (pp. 487-511). New York: Oxford University Press.

Bourdieu, P. (1986). The forms of capital. In J. G. Richardson (Ed.), Handbook of theory and research for the sociology of education (pp. 241-258). New York: Greenwood Press.

Brown v. Board of Education, 347 U.S. 483 (1954).

Brown, C. M., II. (2001). Collegiate desegregation and the public Black college: A new policy mandate. The Journal of Higher Education, 72(1), 46-62.

Brown, C. M., II, \& Davis, E. J. (2001). The historically Black college as social contract, social capital, and social equalizer. Peabody Journal of Education, 76(1), 31-49.
Brown, C. M., II, Donahoo, S., \& Bertrand, R. D. (2001). The Black college and the quest for educational opportunity. Urban Education, 36(5), 533-571.

Civil Rights Act of 1964 (Title VII), 42 U.S.C. 2000e et seq. 29 C.F.R. 1600-1610.

Coleman, J. S. (1988). Social capital in the creation of human capital. The American Journal of Sociology, 94(Suppl), 95-120.

Craig. K. (2006). Factors that influence success for African American students. In F. W. Hale (Ed.), How Blacks empower Black students: Lessons for higher education (pp. 101-108). Sterling, VA: Stylus.

Creswell, J. W. (2003). Qualitative inquiry and research design: Choosing among five traditions. Thousand Oaks, CA: Sage.

Davis, J. E. (1994). College in Black and White: Campus environment and academic achievement of African American males. The Journal of Negro Education, 63(4), 620-633.

Davis, J. E. (1999). What does gender have to do with the experience of African American college men. In V. C. Polite \& J. E. Davis (Eds.), African American males in school and society: Practices and policies for effective education (pp. 134-148). New York: Teacher College Press.

Davis, L. A. (2006). Success against the odds: The HBCU experience. In F. W. Hale (Ed.), How Blacks empower Black students: Lessons for higher education (pp. 43-50). Sterling, VA: Stylus.

Davis, S., Jenkins, G., \& Hunt, R., Page, I. F. (2002). The pact. New York: Riverhead Books.

Days, D. S. (1992). Brown blues: Rethinking the integrative ideal. William and Mary Law Review, 34, 53-74.

De Sousa, D. J., \& Kuh, G. D. (1996). Does institutional racial composition make a different in what Black students gain in college? The Journal of College student Development, 37(3), 257-267.

Drewry, H. N., \& Doermann, H. (2004). Stand and prosper: Private Black college and their students. Princeton: Princeton University Press.

Eimers, M., \& Pike, G. (1997). Minority and non-minority adjustment to college: Differences or similarities. Research in Higher Education, 38(1), 77-97.

Farmer-Hinton, R. L., \& Adams, T. L. (2006). Social capital and college preparation: Exploring the role of counselors in a college prep school for Black students. The Negro Educational Review, 57(1-2), 101-116.

Feagin, J. R., Vera, H., \& Imani, N. (1996). Agony of education. New York: Routledge.

Fleming, J. (1976). The lengthening shadow of slavery: A historical justification for affirmative action for Blacks in higher education. Washington, DC: Howard University Press.

Fleming, J. (1984). Blacks in college: A comparative study of student success in Black and White institutions. San Francisco: Jossey-Bass.

Freeman, K., \& Cohen, R. (2001). Bridging the gap between economic development and cultural empowerment: HBCUs' challenges for the future. Urban Education, 36(5), 585-596.

Fries-Britt, S. (1997). Identifying and supporting gifted African American men. In M. J. Cuyjet (Ed.), Helping African American men succeed in college (pp. 5-16). San Francisco: Jossey-Bass. 
Fries-Britt, S. (1998). Moving beyond Black achiever isolation: Experience of gifted Black collegians. The Journal of Higher Education, 69(5), 556-576.

Fries-Britt, S., \& Turner, B. (2002). Uneven stories: Successful Black collegians at a Black and a White campus. The Review of Higher Education, 25(3), 315-330.

Garibaldi, A.M. (1997). Four decades of progress . . . and decline: An assessment of African American educational attainment. The Journal of Negro Education, 66(2), 105-120.

Green, P. (2000). African American men and the academy. In L. Jones (Ed.), Brothers of the academy: Up and coming Black scholars earning our way in higher education (pp. 2-20). Sterling, VA: Stylus.

Green, P. (2001). The policies and politics of retention and access of African American in public White Institutions. In L. Jones (Ed.), Retaining African Americans in higher education: Challenging paradigms for retaining students, faculty and administrator (pp. 45-58). Sterling, VA: Stylus.

Guiffrida, D. (2005). Othermothering as framework for understanding African American students' definitions of student-centered faculty. The Journal of Higher Education, 76(5), 702-723.

Harper. S. R. (2006). Peer support for African American male college achievement: Beyond internalized racism and the burden of acting White. The Journal of Men's Studies, 14(3), 337-358.

Harper, S. R. (2007). High achieving African American men's behavioral responses to stereotypes at predominantly White universities. Manuscript submitted for publication.

Harper, S. R., Carini, R., Bridges, B., \& J. Hayek, (2004). Gender differences in student engagement among African American undergraduates at historically Black colleges and universities. Journal of College Student Development, 45(3), 271-284.

Hoffman, K., Liagas, C., \& Snyder, T. D. (2003). National Center for Education Statistics. Status and trends in the education of Blacks. Washington, DC: U.S. Department of Education. Retrieved March 14, 2006, from http://nces. ed.gov/pub2003/2003034.pdf

Holsendolph, E. (2005). My brothers' keeper. Diverse Issues in Higher Education, 22(18), 22-25.

Jones, R. S., Torres, V., \& Arminio, J. (2006). Negotiating the complexities of qualitative research in higher education: Fundamental elements and issues. New York: Taylor and Francis.

Kimbrough, W. M., \& Harper, S. R. (2006). African American men at Historically Black colleges and universities: Different environments, similar challenges. In M. J. Cuyjet. (Ed.). African American men in college (pp. 189-209). San Francisco: Jossey-Bass.

Kim, M. (2002). Historically Black vs. White institutions: Academic development among Black students. Review of Higher Education, 25(4), 385-407.

Kim, M., \& Conrad, C. F. (2006). The impact of historically Black colleges and universities on the academic success of African American students. Research in Higher Education, 47(4), 399-427.

Kuh, G. D., Douglass, K. B., Lund, J. P \& Ramin-Gyurnek, J. (1994). Student learning outside the classroom: Transcending artificial boundaries. ASHE-ERIC Higher Education report no. 8. Washington D.C.: The George Washington University, Graduate School of Education and Human Development.

Lavant, B. D., Anderson, J., \& Tiggs, J. W. (1997). Retaining African American men through mentoring initiatives. In M. J., Cuyjet. (Ed.), Helping African American men succeed in college. New Directions for Student Services (pp. 43-52). San Francisco: Jossey-Bass.

Lin, N. (2001). Social capital: A theory of social structure and action. New York: Cambridge University Press.

Merriam, S. B. (1998). Qualitative resign and case study applications in educations. San Francisco: Jossey-Bass.

Moore, J. L., III. (2001). Developing academic warriors: Things that parents, administrators, and faculty should know. In L. Jones (Ed.), Retaining African Americans in higher education: Challenging paradigms for retaining students, faculty, and administrators (pp. 77-90). Virginia: Stylus.

Outcalt, C. L., \& Skewes-Cox, T. E. (2002). Involvement, interaction and satisfaction: The human environment at HBCUs. The Review of Higher Education, 25(3), 331-347.

Pascarella, E. T., \& Terenzini, P. T. (2005). How college affects students: A third decade of research (3rd ed.). San Francisco: Jossey-Bass.

Perna, L. W. (2001). The contribution of historically Black colleges and universities and preparation of African American faculty careers. Research in Higher Education, 42(3), 267-292.

Perna, W. L., \& Titus, M. A. (2005). The relationship between parental involvement as social capital and college enrollment: An examination of racial/ethnic group differences. The Journal of Higher Education, 76(5), 485-518.

Provasnik, S. Shafer, L, L., \& Snyder, T. D. (2004). Historically Black college and universities, 1796-2001. National Center for Educational Statistics: Washington, DC: U.S. Department of Education. Retrieved on March 13, 2006, from http://nces.ed.gov/pubs2004/2004062.pdf

Rankin, S. R., \& Reason, R. D. (2005). Differing perceptions: How students of color and White students perceive campus climate for underrepresented groups. Journal of College Student Development, 46(1), 43-61.

Roebuck, J. B., \& Murty, K. S. (1993). Historically Black colleges and universities: Their place in American higher education. Westport, CT: Praeger.

Ross, M. (1998). Success factors of young African American males at a historically Black college. Westport, CT: Bergin and Garvey.

Seifert, T.A., Drummon, J., \& Pascarella, E. T. (March/April 2006). African American students' experiences of good practices: A comparison of institutional type. Journal of College Student Development, 47(2), 185-205.

Smith, B. (2007). Accessing social capital through the academic mentoring process. Equity and Excellence in Education, 40(1), 36-46.

Stefkovich, J. A., \& Leas, T. (1994). A legal history of desegregation in higher education. The Journal of Negro Education, 63(3), 406-420.

Tatum, B. D. (1997). Why are all the Black kids sitting together in the cafeteria? And other conversations about race. New York: Basic Books.

Tierney, W. G., \& Venegas, K. M. (2006). Fictive kin and social capital: The role of peer groups in applying and paying for college. American Behavioral Scientist, 49(12), 1687-1702. 
Tinto, V. (1987). Leaving college. Chicago: The University of Chicago Press.

Thomas, S. I. (2000). Ties that bind: A social network approach to understanding student integration and persistence. The Journal of Higher Education, 71(5), 591-615.

United Negro College Fund, www.uncf.org, accessed March 6, 2007.

United States v. Fordice, 112 S. Ct. 2727 (1992).

Wallace, D., Abel, R., \& Ropers-Huilman, B. (2000). Clearing a path for success: Deconstructing borders through undergraduate mentoring. The Review of Higher Education, 24(1), 87-102.

Watson, J. (2006). CUNY retention programs for African American males under fire. Diverse Issues in Higher Education, 23(9), p. 7.
Watson, L., Terrell, M. C., Wright, D. J., \& Bonner, F. A., Cuyjet, M. J., Gold, J. A., et al. (2002). How minority students experience college: Implications for planning and policy. Sterling, VA: Stylus

Wenglinsky, H. H. (1996). The educational justification of historically Black colleges and universities: Policy responses to the U.S. Supreme Court. Educational Evaluation and Policy Analysis, 18, 91-103.

Yin, R. K. (2006). Case study methods. In J. L. Green, G. Camilli, \& P. B. Elmore (Eds.), Handbook of complementary methods in education research (pp. 111-122). Mahwah, NJ: Lawrence Erlbaum. 